Adenyl cyclase parathyroid hormone prostaglandin $\mathrm{E}_{1}$ vasopressin

\title{
The Effect of Parathyroid Hormone on Rabbit Renal Cortex Adenyl Cyclase during Development
}

\author{
Louie G. Linarelli, ${ }^{[29]}$ John Bobik, and Caroline Bobik \\ Department of Pediatrics, Mercy Hospital and Children's Hospital of the University of Pittsburgh, Pittsburgh, Pennsylvania, USA
}

Extract

Renal cortex from fetal and neonatal rabbits (from 4-5 days preterm to 4 days of age) shows results comparable with maternal renal cortex during in vitro stimulation of the 2,200 $\times g$ pellet with parathyroid hormone $(\mathrm{PTH})$ at $20 \mu \mathrm{g} / \mathrm{ml}$. Incubation with sodium fluoride $(10 \mathrm{~mm})$, a nonspecific potent stimulator of adenyl cyclase, resulted in comparable increases in both the fetal and the maternal renal cortex. Glucagon, prostaglandin $\mathrm{E}_{1}$, and vasopressin, all at $20 \mu \mathrm{g} / \mathrm{ml}$, stimulate adenyl cyclase to a lesser extent than PTH. Homogenates of full term neonatal rabbits and maternal renal cortex show comparable phosphodiesterase enzyme levels with or without $0.04 \mathrm{~m}$ imidazole. These data show that in fetal and early neonatal renal cortex there is no developmental adenyl cyclase responsiveness to PTH. Similarly, phosphodiesterase is present equally in term and maternal rabbit renal cortex.

\section{Speculation}

A maturational response of adenosine $3^{\prime}, 5^{\prime}$-monophosphate (cyclic AMP) in urine to PTH has been previously suggested in the human full term neonate. This change in responsiveness may not be due to a defect in the $\mathrm{PTH}$ hormone receptor or the adenyl cyclase enzyme of the proximal renal tubule. Other causes, such as impaired proximal tubular transport of cyclic AMP, may account for this maturational response.

\section{Introduction}

The physiologic action of PTH on bone [6], kidney cortex $[4,5,14,15,19]$, and renal tubules $[14]$ is mediated through activation of adenyl cyclase, the enzyme which catalyzes the conversion of adenosine triphosphate to cyclic AMP. Activation of adenyl cyclase results in increased cyclic AMP in renal parenchyma [16, $18]$ and increased cyclic AMP excretion in urine $[1,2$, 4, 8]. Full term newborn infants have been shown to have a diminished responsiveness to PTH infusions and a developmental increase in responsiveness during the first few days of life [11]. Maturation of renal cortical adenyl cyclase in human neonates as an expla- nation for the increasing cyclic AMP response to PTH has not been reported. The present series of experiments was performed to evaluate developmental adenyl cyclase responsiveness to $\mathrm{PTH}$ in the rabbit renal cortex. Studies with glucagon, prostaglandin $\mathrm{E}_{1}$, and vasopressin were made in order to demonstrate whether the adenyl cyclase receptor sites were as hormone specific in fetal rabbit renal cortex as in mature rabbit renal cortex. Phosphodiesterase measurements were made in order to indicate whether diminished cyclic AMP excretion could be attributed to increased breakdown of cyclic AMP by higher levels of phosphodiesterase in the neonate. 


\section{Materials and Methods}

Renal cortex was obtained from pregnant New Zealand White rabbits, newborn rabbits $1-4$ days of age, and fetuses delivered by cesarean section from 5 days preterm to term. The limitation of kidney size prevented the study of the renal cortex in younger fetuses because of the difficulty of separating cortex from medulla. The does were maintained on carefully controlled normal ( $16 \%$ protein) diets for at least 30 days before conception.

Portions of the renal cortex were prepared by free dissection with as much of the cortex as possible being used in each experiment. Adenyl cyclase activity was measured according to the method of Krishna et al. [10]. The slices were weighed and homogenized immediately by hand in a glass homogenizer. The buffer used was Tris- $\mathrm{HCl}$ ( $\mathrm{pH} 7.6$ ), which contained $5 \mathrm{~mm}$ $\mathrm{MgCl}_{2}, 0.08 \%$ bovine serum albumin, and $10 \mathrm{~mm}$ theophylline. Homogenates of adult and fetal renal cortex were centrifuged at $900 \times g, 2,200 \times g, 10,000 \times g$, and $100,000 \times g$. The resuspended pellets from centrifugations at these speeds showed the major adenyl cyclase activity to be at $2,200 \times g$ and less. We selected $2,200 \times g$, to best compare with the work of other investigators $[5,14]$. In a series of experiments performed at $\mathrm{pH}$ values ranging from 6.8 to 8 , the optimum $\mathrm{pH}$ for both fetal and maternal renal cortex studies was found to be 7.6. The homogenate was spun at $2,200 \times g$ for $10 \mathrm{~min}$, and the pellet was resuspended in buffer for use in the assay. One microcurie of adenosine $5^{\prime}-\left(8-{ }^{14} \mathrm{C}\right)$ triphosphate, $53.4 \mathrm{mCi} / \mathrm{mm}$, was used per assay tube. The final reaction mixture for the assay of adenyl cyclase contained $1.2 \mathrm{~mm}$ labeled ATP, $5 \mathrm{~mm} \mathrm{MgCl}_{2}, 10 \mathrm{~mm}$ theophylline, $0.08 \%$ bovine serum albumin, and membrane fraction equivalent to $800-1,200 \mu \mathrm{g}$ protein in $0.150 \mathrm{ml} 50 \mathrm{~mm}$ Tris- $\mathrm{HCl}, \mathrm{pH}$ 7.6. Hormone additives were PTH $(20 \mu \mathrm{g} / \mathrm{ml})$, glucagon $(20 \mu \mathrm{g} / \mathrm{ml})$, vasopressin $(20 \mu \mathrm{g} / \mathrm{ml})$, or sodium fluoride $(10 \mathrm{~mm})$. The reaction was carried out at $37^{\circ}$ for $3 \mathrm{~min}$ and stopped by placing in boiling water for $2 \mathrm{~min}$, after which cyclic AMP $(0.5 \mathrm{mg} / 0.100 \mathrm{ml})$ was added. Tubes were placed in an ice bath for $10 \mathrm{~min}$, followed by the addition of $0.4 \mathrm{ml}$ distilled water. The tubes were centrifuged at $2,000 \mathrm{rpm}$ at $4^{\circ}$ for $15 \mathrm{~min}$. The supernatant was passed through a column $(5 \times 15$ $\mathrm{mm}$ ) of Dowex AG $50 \mathrm{WX} 4$ followed by $3 \mathrm{ml}$ distilled water. The eluant was discarded. The column was eluted with another $3 \mathrm{ml}$ distilled water and a 3-ml fraction was collected. This fraction was precipitated twice with $0.2 \mathrm{ml} 8.3 \% \mathrm{Ba}(\mathrm{OH})_{3}$ and $0.2 \mathrm{ml} 5 \%$
$\mathrm{ZnSO}_{4}$, vortexed, and spun at $2,000 \mathrm{rpm}$ at $4^{\circ}$ for 10 $\mathrm{min}$. Three milliliters of the supernatant were added to $15 \mathrm{ml}$ Bray's cocktail and counted on a Tri-Carb liquid scintillation counter [21]. Recoveries were checked by optical densities and by addition of cyclic $\left({ }^{3} \mathrm{H}\right) \mathrm{AMP}$ at initiation of the reaction.

Phosphodiesterase was determined by the method of Butcher and Sutherland which measures total enzyme activity; tissues were prepared by immediate homogenization in $0.25 \mathrm{M}$ sucrose [3].

Protein concentrations were determined by the method of Lowry [12].

Adenosine $\quad 5^{\prime}-\left(8-{ }^{14} \mathrm{C}\right)$ triphosphate was purchased from Schwartz/Mann [22]. Parathyroid hormone was obtained from Wilson Laboratories [23], vasopressin from Mann Research Laboratories [24], and glucagon from Lilly [25]. Prostaglandin $\mathrm{E}_{1}$ was a gift [26].

\section{Results}

Renal cortex from the fetal and neonatal rabbit from 4-5 days preterm to 4 days of age shows adenyl cyclase response to PTH (final concentration $20 \mu \mathrm{g} / \mathrm{ml}$ ) comparable with the maternal renal cortex (Fig. 1). No difference was noted between the pregnant and non-

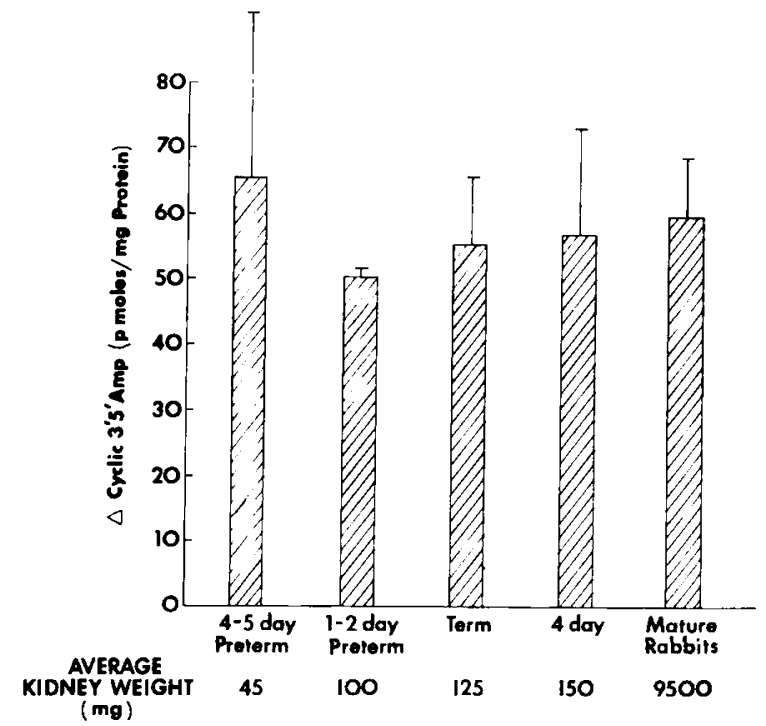

Fig. 1. In vitro stimulation with parathyroid hormone (PTH) at $20 \mu \mathrm{g} / \mathrm{ml}$ of rabbit renal cortex from fetus or neonates of does fed $16 \%$ protein diets are compared with the cortex from the doe. Mean \pm SD of the rise over control values are shown. Individual experiments with fetuses or neonates were performed by combining the kidneys from a litter. Twelve to sixteen litters were used for experiments for each age group. Twelve adult rabbits were used for comparison. Cyclic $3^{\prime}, 5^{\prime}$ Amp: adenosine $3^{\prime}, 5^{\prime}$-monophos. phate. 
Table I. Comparison of hormone effects of adenyl cyclase of renal cortex in mature versus fetal rabbits ${ }^{1}$

\begin{tabular}{|c|c|c|}
\hline \multirow{2}{*}{ Addition } & \multicolumn{2}{|c|}{$\begin{array}{l}\text { Adenyl cyclase activity, } \\
\text { pmol/mg protein }\end{array}$} \\
\hline & $\begin{array}{l}\text { Mature (3), } \\
\text { mean } \pm \text { SD }\end{array}$ & $\begin{array}{l}\text { In utero (3), } \\
\text { mean } \pm \mathrm{SD}\end{array}$ \\
\hline None & $45.2 \pm 1.61$ & $51.1 \pm 14.0$ \\
\hline $\mathrm{NaF}, 10^{-2} \mathrm{M}$ & $200.0 \pm 14.0$ & $232.2 \pm 26.0$ \\
\hline $\begin{array}{l}\text { Parathyroid hormone, } \\
20 \mu \mathrm{g} / \mathrm{ml}\end{array}$ & $115.3 \pm 23.7$ & $114.1 \pm 11.9$ \\
\hline Glucagon, $20 \mu \mathrm{g} / \mathrm{ml}$ & $53.9 \pm 0.7$ & $60.6 \pm 18.3$ \\
\hline $\begin{array}{l}\text { Prostaglandin } E_{1}, 20 \\
\mu \mathrm{g} / \mathrm{ml}\end{array}$ & $81.8 \pm 18.4$ & $80.4 \pm 7.6$ \\
\hline Vasopressin, $20 \mu \mathrm{g} / \mathrm{ml}$ & $52.6 \pm 5.2$ & $65.7 \pm 14.9$ \\
\hline
\end{tabular}

${ }^{1}$ Numbers in parentheses represent the number of experiments. Fetal experiments represent renal cortex from litters of six to eight fetuses from 4-5 days before term.

pregnant doe and between male and female rabbits (results not shown).

Sodium fluoride is a known stimulator of adenyl cyclase in numerous tissues [17]. Table I shows control adenyl cyclase levels and $\mathrm{NaF}$-stimulated levels in renal cortex from does compared with their fetuses from 4-5 days preterm. Other hormones with known minimal effect on the renal cortical adenyl cyclase of mature animals are shown in Table $I$ for comparison with PTH. Glucagon $(20 \mu \mathrm{g} / \mathrm{ml})$ and prostaglandin $\mathrm{E}_{1}$ $(20 \mu \mathrm{g} / \mathrm{ml})$ stimulated renal cortex from both neonates and does to a lesser degree than parathyroid hormone, whereas vasopressin produced the least response of these hormones. There were no discernable differences between the responses of fetal and of maternal rabbit renal cortex from fetuses and does to these hormones.

Table II shows the renal cortical phosphodiesterase values for full term neonatal rabbits compared with their mothers. The basal levels for control tissue were lower for the infants, but the results were statistically

Table II. Comparison of full term neonatal and maternal rabbit renal cortex phosphodiesterase ${ }^{1}$

\begin{tabular}{|c|c|c|}
\hline & \multicolumn{2}{|c|}{$\begin{array}{l}\text { In vilro homogenate phosphodiesterase, } \\
\mu \mathrm{mol} \mathrm{P} / \mathrm{g} / 30 \mathrm{~min} \text { at } 30^{\circ} \text { (Mean } \pm \text { range) }\end{array}$} \\
\hline & Without imidazole & With imidazole \\
\hline Neonate $(4)^{3}$ & $23.9 \pm 3.8$ & $34.1 \pm 5.3$ \\
\hline Mature $(4)^{3}$ & $29.9 \pm 11.1$ & $38.3 \pm 7.3$ \\
\hline
\end{tabular}

${ }^{1}$ Rabbit renal cortex homogenates were assayed with and without $0.04 \mathrm{~m}$ imidazole in vitro.

2 Phosphodiesterase is measured as micromoles of phosphate per gram of tissue at $30^{\circ}$ for 30 min of incubation.

${ }^{3}$ Numbers in parentheses represent four litters of six to eight rabbits for neonatal renal cortex and four does for comparison. insignificant. Imidazole stimulation yielded comparable levels in infants and mothers.

\section{Discussion}

We have shown recently that full term human newborn infants demonstrate a maturational increase in excretion of cyclic AMP in urine in response to PTH stimulation over the first 3 days of life [11]. The response of cyclic AMP in urine to PTH on the 1st day of life was minimal and increased by 3 days of age, but was still less than the adult response. The present studies would suggest that this maturational renal proximal tubular responsiveness to PTH in the human neonate may not be due to development of the adenyl cyclase enzyme. Results of our studies on rabbit renal cortex indicate that PTH-sensitive adenyl cyclase comparable with that of the mature animal is present in the fetal cortex from at least $4-5$ days preterm. This has also been demonstrated in the whole kidney of fetal rats throughout fetal development [9].

We cannot apply this animal clata directly to the human neonate. However, by comparison, it would appear less likely that either a defect in the PTH hormone receptor or in the adenyl cyclase enzyme is responsible for the diminished $\mathrm{PTH}$ responsiveness in the neonate. This conclusion is substantiated by the recent demonstration of $\mathrm{PTH}$-sensitive adenyl cyclase from the renal cortex of a patient with pseudohypoparathyroidism [13]. These patients have a diminished excretion of cyclic AMP in urine in response to $\mathrm{PTH}$ stimulation [9, 17]. Broadus et al. [2] have speculated on an active renal tubular secretion of cyclic AMP. Thus, patients with pseudohypoparathyroidism, as well as the neonate, need to be investigated in relation to such hypotheses as deficient transport of cyclic AMP.

Sodium fluoride is a known potent stimulator of adenyl cyclase in most tissues studied [17] including mature renal cortex $[5,14,15,19]$. There is no apparent difference in the ability of adenyl cyclase from renal cortex of fetal and maternal rabbits to respond to $\mathrm{NaF}$ stimulation. In common with other investigators, we have not been able to attribute any significance to the increase in activity produced by $\mathrm{NaF}$. Investigation of the adenyl cyclase response to glucagon, vasopressin, and prostaglandin $\mathrm{E}_{\mathbf{1}}$ led to the same conclusion. We were unable to demonstrate any difference in the response of renal cortex adenyl cyclase from fetal and mature rabbits to these hormones which are known stimulators of this enzyme. 
Phosphodiesterase converts cyclic AMP to 5'-AMP. An elevated level of this enzyme in the renal cortex of human neonates could account for the diminished cyclic AMP output in urine in terms of increased degradation rather than decreased production. Because of the obvious difficulties in studying human neonatal tissue, rabbit renal cortex was again chosen. We were unable to clemonstrate any significant difference in phosphodiesterase levels between neonatal and maternal tissue, even in the presence of imidazole, a potent stimulator of this enzyme [3]. The existence of at least two phosphodiesterases with different $\mathrm{K}_{\mathrm{m}}$ values has recently been shown, one acting preferentially on cyclic AMP and one on guanosine 3,5'-monophosphate [20]. It is possible that further study might indicate that these enzymes are present in varying proportions during fetal developmental stages which could alter the conclusions of our study.

We believe that the studies described here are important in the search for a mechanism for the developmental responsiveness to PTH. However, human fetal renal tissue must be studied in the future. The present studies suggest that PTH developmental response is not on a hormone receptor or an adenyl cyclase enzyme level. In addition, phosphodiesterase cannot be implicated in increased cyclic AMP degradation. In the future, a defective transfer system of this nucleotide should be examined as a possible mechanism for the maturational response in infants.

\section{Summary}

The adenyl cyclase enzyme is present in the renal cortex of the fetal rabbit from at least 4-5 days preterm and is as responsive to PTH stimulation as adenyl cyclase from the maternal renal cortex. The enzyme phosphodiesterase which causes degradation of cyclic AMP is also present equally in term and maternal rabbit renal cortex. The data cannot be directly applied to the human neonate. However, by comparison, neither a defect in the PTH hormone receptor nor in the adenyl cyclase of the renal proximal tubule is a probable cause of decreased cyclic AMP output in urine in response to $\mathrm{PTH}$ stimulation of the neonate. Because elevated phosphodesterase levels are not found, the decreased output in urine cannot be explained in terms of increased cyclic AMP breakdown.

\section{References and Notes}

1. Alrbach, G. D., Potts, J. T., Jr., Chase, L. R., and Melson, G. L.: Polypeptide hormones and calcium metabolism. Ann. Intern. Med., 70: 1234 (1969).
2. Broadus, A. E., Kaninskr, N. I., Northcutt, R. C., Hardman, J. G., Sutherlaid, E. W., ANd Liddle, G. W.: Effects of glucagon on adenosine $3^{\prime}, 5^{\prime}$-monophosphate and guanosine $3^{\prime}, 5^{\prime}$-monophosphate in human plasma and urine. J. Clin. Invest., 49: $2237(1970)$.

3. Butcher, R. W', And Sutherland, E. W.: Adenosine 3',5'phosphate in biological materials. I. Purification and properties of cyclic $3^{\prime}, 5^{\prime}$-nucleotide phosphodiesterase and use of this enzyme to characterize adenosine $3^{\prime}, 5^{\prime}$-phosphate in human urine. J. Biol. Chem., 237: 1244 (1962).

4. Chase, L. R., AND Aurbach, G. D.: Parathyroid function and the renal excretion of $3^{\prime}, 5^{\prime}$-adenylic acid. Proc. Nat. Acad. Sci. U. S. A., 58: $518(196 \bar{\imath})$.

5. Chase, L. R., ANd Aurbach, G. D.: Renal adenyl cyclase: Anatomically scparate sites for parathyroid hormone and vasopressin. Science, 159: 545 (1968).

6. Chase, L. R., Fedak, S. A., And Aurbach, G. D.: Activation of skeletal adenyl cyclase by parathyroid hormone in vitro. Endocrinology, 84 : 761 (1969).

7. Chase, L. R., Melson, G. L., and Aurbach, G. D.: Pseudohypoparathyroidism: Defective excretion of $3^{\prime}, 5^{\prime}$-AMP in response to parathyroid hormone. J. Clin. Invest., 48: 1832 (1969).

8. Kaminsky, N. I., Broadus, A. E., Hardman, J. G., Jones, D. J, Jr., Ball, H., Sutherland, E. W., and Lidde, G. W.: Effects of parathyroid hormone on plasma and urinary adenosine $3^{\prime}, 5^{\prime}$-monophosphate in man. J. Clin. Invest., 49: 2387 (1970).

9. Kaplan, S. A., Thayer, K. H., Lippe, B. M., and Wong, S. L. R.: Cyclic AMP production in the rat fetus and newborn: Effects of glucagon and parathormone. Pediat. Res., 6: $35 \mathrm{I}$ (1972).

10. Krishna, G., Wfiss, B., ANd Brodie, B. B.: A simple sensitive method for the assay of adenyl cyclase. J. Pharmacol. Exp. Ther., 163: 379 (1968).

11. Linarelli, L. G., Bobik, J., And Bobik, C.: Newboin urinary cyclic AMP and developmental renal responsiveness to parathyroid hormone. Pediatrics, 50: 14 (1972).

12. Lowry, O. H., Rosebrough, N. J., Farr, A. L., and Randal.L, R. J.: Protein measurement with Folin phenol reagent. J. Biol. Chem., 193: 265 (1951).

13. Marcus, R., Wrlber, J. R., and Aurbach, G. D.: Parathyroid hormone-sensitive adenyl cyclase from the renal cortex of a patient with pseudohypoparathyroidism. J. Clin. Endocrinol., 33: 537 (1971).

14. Melson, G. L., Chase, L. R., and Aurbach, G. D.: Parathyroid hormone-sensitive adenyl cyclase in isolated renal tubules. Endocrinology, 86: 511 (1970).

15. Murad, F., Brewer, H. B., JR., And Vaughan, M.: Effect of thyrocalcitonin on adenosine $3^{\prime}, 5^{\prime}$-cyclic phosphate formation by rat kidney and bone. Proc. Nat. Acad. Sci. U. S. A., 65: 446 $(1970)$.

16. Nagata, N., and Rasmussen, H.: Parathyroid hormone and renal cell metabolism. Biochemistry, $7: 3728$ (1968).

17. Rall, T. W., and Sutherland, E. W.: Formation of a cyclic adenine ribonucleotide by tissue particles. J. Biol. Chem., 232: 1065 (1958).

18. Rasmussen, H., and Trnehouse, A.: Gyclic adenosine monophosphate, $\mathrm{Ca}^{++}$and membranes. Proc. Nat. Acad. Sci. U. S. A., 59: 1364 (1968). 
19. Streeto, J. M.: Renal cortical adenyl cyclase: Effect of parathyroid hormone and calcium. Metabolism, 18: 968 (1969).

20. Thompson, W. J., AND Appleman, M. M.: Characterization of cyclic nucleotide phosphodiesterases of rat tissue. J. Biol. Chem., 246: 3145 (1971).

21. Packard Instrument Company, Downer's Grove, Ill

22. Schwartz/Mann, Orangeburg, N. Y.

23. Wilson Laboratories, Chicago, Ill.

24. Mann Research Laboratories, Orangeburg, N. Y.

25. Eli Lilly \& Co., Indianapolis, Ind.

26. From Dr. John E. Pike, Upjohn Company.
27. We wish to thank Mr. Paul Labash for his expert technical assistance, and Mrs. Barbara Mudrany for secretarial assistance. We also wish to thank Mr. Floyd Shaw for his painstaking care in feeding controlled diets at his breeding kennels in Bentleyville, Pennsylvania.

28. This work was supported in part by Health Research and Service Foundation Grant no. M-30.

29. Requests for reprints should be addressed to: LouIE G. Linarelli, M.D., Department of Pediatrics, Mercy Hospital, Pride and Locust Streets, Pittsburgh, Penn. 15219 (USA).

30. Accepted for publication July 12, 1973. 